\title{
Academic Supervision Management to Support School Literacy Movement
}

\author{
Sudi Piyambodo ${ }^{1, *}$ \\ ${ }^{1}$ Madrasah Tsanawiyah Negeri 3 Garut, Garut, Indonesia \\ ${ }^{*}$ Corresponding author. Email: rizqiapriyambodo@yahoo.co.id
}

\begin{abstract}
This research aims to determine the influence of Academic supervision management by Madrasah principals on Mathematics learning quality to support school literacy movement in the Madrasah Tsanawiyah (Islamic State Junior High School) in Garut Regency, West Java. The research applied a survey method with a correlational research design. Data were collected using a questionnaire instrument developed by the writer. All research data were analyzed using regression analysis. The respondents were determined by considering the existing level within the entire population into research respondents, that was, the quantity was 18 teachers. The research result showed a positive and significant correlation between academic supervision management conducted by the Madrasah Principal with the teachers' instruction effectiveness, and the coefficient correlation score is $r_{y}=0.508$. The result indicates that the better the academic supervision of the Madrasah principal, the better mathematics instruction's quality. The implication of this research can motivate students to be more serious in studying mathematics.
\end{abstract}

Keywords: Academic supervision, Management, Quality of learning, Literacy.

\section{INTRODUCTION}

The Covid-19 pandemic has a massive effect on various sectors in life, including education; many educational institutions, including Madrasah, were required to be adaptive in conducting the educational process. The role of the Madrasah principal is vital in improving the quality of education and Madrasah performance. Referring to the concept of effective Madrasah, the Madrasah Principal, as the highest authority position, needs to apply a policy aiming at Madrasah's vision-mission[1].

The importance of the quality in mathematics education and re-orienting mathematics instruction in the class are the issues that need to be addressed[2]. Various efforts to improve the quality of mathematic instruction have been conducted through many different approaches, strategies, and methods in the implementation of education[3]; however, the essential matter which was very crucial and had not yet been taken into account is the academic supervision management on mathematics teachers.
Academic supervision has several objectives for principals and teachers, including monitoring the quality of teaching teachers, growing motivation, and developing teacher professionalism. With academic supervision, teachers are more serious in preparing their teaching materials and of course, they can choose the best teaching methods so that learning can be achieved by students. If the management of academic supervision does not go well, of course, it will have consequences that make teaching in the madrasa run mediocre or even worse so that learning does not develop properly and will even experience a setback [4], [5], [6].

Based on the research result in several Madrasah on academic supervision, it needs to be improved[7], [8]. Similar to the deduction, research asserts that academic supervision leads to increasing teachers' professionalism and quality of graduates; that is, teachers can find and fix their weaknesses and lack ness in teaching-studying activities: in terms of instruction, the teachers' skills may improve better[9].

Based on the above problems, the researcher deems it essential to conduct a study to follow up regarding the 
quality of teachers' instruction through academic supervision. In this case, the academic supervision intended is an attempt by the Madrasah Principal to provide planned guidance to mathematic teachers to improve their class instruction[10]. This research result is beneficial to determine a policy decision to improve the quality of mathematics teachers' instruction in Madrasah.

\section{METHODS}

This research aims to describe the effect of supervision management by Madrasah Principal on the quality improvement of mathematic instruction to support school literacy movement in State Madrasah Tsanawiyah or Islamic Junior High School in Garut Regency. The research method applied was a survey method using a correlational approach. Employing this method was expected to solve educational institutions' problems regarding the improvement in learning quality.

This research was conducted in three State Madrasah Tsanawiyah located in Garut Regency. The samples were 18 out of 45 population taken by proportional random sampling. The data collected in this research used a questionnaire as the instrument. The instrument trial test was conducted through Moment Pearson's product correlation method. The reliability test for the research instrument used the Alpha Cronbach calculation. Meanwhile, the data analysis used inferential analysis by applying the analysis of variance and regression. The flowchart of the research procedure is shown in following figure.

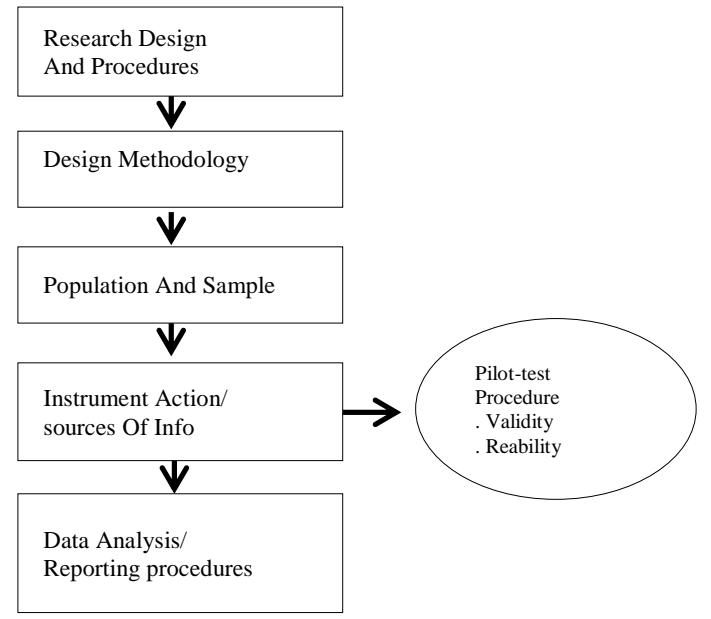

Figure 1. The Flowchart of Research Procedures.

\section{RESULTS AND DISCUSSION}

The quality improvement for education cannot be separated from teachers' competency; consequently, it needs qualified and sustainable management of teachers' development competency because the teachers' competency enhancement itself is one of the indicators for teachers' professionalism[10]. The demand for an internal supervision program in the Madrasah through academic supervision by the Madrasah principal becomes an alternative to improving and developing teachers' quality in Madrasah[12].

The task of academic supervision by the Madrasah principal is not just conducting a routine visit to the class without inspecting the technical instruction and controlling educational quality in Madrasah [13]. In this case, such supervision is a management activity applied by the madrasah principal. The academic supervision management by the Madrasah principal should be carried out precisely and sustainably, including the stages of planning of academic supervision, organizing academic supervision, implementing academic supervision, and supervising academic supervision [14].

Initially, the madrasah principal plans academic supervision toward mathematic teachers by arranging a plan for academic supervision. In this planning stage, the madrasah principal sets up the plan covering determining the purpose in the implementation of academic supervision, identifying instruction problems, determining supervision method and approach, making a study document instrument and class visit observation instrument, and drafting schedule for class inspection supervision[15].

The subsequent process in academic supervision planning is the madrasah principal along with madrasah vice-principal of curriculum determine the objective of academic supervision which will be conducted, and for the objective of academic supervision is to improve teachers' professionalism in planning, to perform, and to assess instruction and provide services and assistance to the teachers for improving their quality. After determining the objective in such supervision, afterward, the supervisor team identifies problems related to the issue, namely, mathematics instruction currently handled by the teachers[16].

The following activity of academic supervision planning conducted by the madrasah principle is to determine the alternative supervision method and approach, e.g., direct and indirect approach. Meanwhile, it is advised that the academic supervision conducted is not only by employing the method of visiting the class but also applying appropriate methods conforming to the characteristics and requirements of the mathematic teachers[17]. The researcher also discovers the planning process conducted by the Madrasah principal together with the Madrasah vice principal of curriculum, that is, by preparing academic supervision instruments. As for the instrument format applied is by examining instruction administration, the instrument of implementing instruction. This instrument aimed to record the conformity of what is conducted by the supervised teachers with the assessment learning standard of the 2013 curriculum[18]. 
The findings related to the planning process of academic supervision for mathematic teachers by Madrasah principals are the availability of scheduling draft in implementing academic supervision arranged by Madrasah vice principal of curriculum. From this schedule drat, the academic supervision on mathematic teachers planned by the madrasah principal was carried out twice in one school year[19].

The process of organizing academic supervision on mathematic teachers was initiated by establishing a supervisor team, dividing assignments, delegating supervision authority, and distributing the job. The madrasah principal established a supervisor team consisting of the Madrasah vice principal of curriculum and two senior mathematic teachers. Afterward, the established team was handed with letter of assignment by the Madrasah principal[20]. The reason why the madrasah principal needed to establish this supervision team was because the madrasah principal did not have much time relating to the position obligation, and other tasks needed to be addressed simultaneously. Furthermore, the second reason, the Madrasah principal has an educational background, not a mathematic, so that supervisor team was very needed by the Madrasah principal [21].

The following process in organizing academic supervision conducted by the Madrasah principals is that the principal arranges an official meeting with the supervision team. The meeting agenda discusses the plan for conducting academic supervision, dividing supervision tasks, and delegating supervision authority to senior teachers appointed as the supervisor[2].

One of the tasks of the supervision team is to arrange a schedule in implementing academic supervision, including information such as the name of the supervisor, the name of the supervised teacher, subject, days and date of the execution, the lesson hours, or face-to-face lesson hours, basic competency, and subject lesson/lesson material and focus of problems they are dealing. In addition to arranging the schedule, the team also has the task to arrange supervision instruments, such as 1) instrument of examining learning devices; 2) instrument of examining Lesson Plan; 3) Instrument of observation in instructing the lesson; 4) instrument of the assessment in learning outcome; 4) instrument of the supervision result analysis; and 5) follow up program of academic supervision[22].

The implementation of academic supervision on mathematic teachers conducted by the Madrasah principal was at least twice in one school year. The supervision activity's implementation was conducted in three stages, i.e., initial selection, class visit, and followup stages[11].
In the initial supervision stages, before conducting academic supervision by visiting the class, the mathematics teacher must prepare its instruction administration including, the student's attendance list, syllabus, Lesson Plan, textbook, and student's assessment. Subsequently, the supervisor examines the lesson plan document and learning assessment instrument. In examining the lesson plan document, the supervisor investigates the lesson plan document made by the concerned teacher to observe the correlation between the Learning Objective with the Basic Competency, conformity between instruction method with the learning objective, the conformity between the learning objective with the assessment instrument made and assessor observe the learning core of the planned activity. After the supervisor's assessment, they provide recommendations, and it can be continued to the implementation of instruction stages, or the teachers who are about to be supervised must revise their lesson plan previously corresponding to the suggestion by the supervisor. After the lesson plan was confirmed to be complete, the subsequent supervision is by conducting the class inspection [23].

The research results related to the implementation of the class instruction are that the teacher carries out the instruction conforming to the teaching schedule they usually do. The chair/supervisor conducts observation of the learning process starting from opening the instruction, the core learning activity, and the closing activity. The supervisor record and assess the entire instruction process conducted by the teacher[24]. The final result of the supervising activity or academic supervision evaluation conducted by the supervisors is a recommendation based on the finding and the fact of the instruction process carried out by the mathematics teacher within the class. Based on the student's grade classification, the teacher who obtains a Very Good grade (A) and Good (B) grade will be recommended to attain an award from the Madrasah principal. Meanwhile, the teacher who obtains Moderate and Poor grades will be advised to follow some self-development activities for teachers, such as MGMP activity, education and training, and IHT related to the 2013 curriculum instructions. The teacher's development who participated in the self-development program will be monitored every three months by the Madrasah viceprincipal of the curriculum. This monitoring was conducted to ensure that the recommendation provided by the supervisor is worked sustainably and led to a better direction[25].

The academic supervision process conducted by the Madrasah principal to the mathematic teachers, among others, are a) addressing the standard of supervision assessment, b) addressing the implementation of measurement/assessment, c) addressing the process of comparison between the finding result of instruction process with the standard score which has been 
determined, d) creating a follow-up program from the implementation result of the academic supervision[26].

The assessment standard of examining Lesson Plan has consisted of a) lesson identity, b) formulating indicator, c) formulating instruction objective, d) selecting lesson material, e) selecting source of study, $f$ ) selecting learning media, g) learning method, h) instruction scenario and i) planning of assessment research. For the scoring system applied using Likert 13 scale, the provision is that when the score is 1 , no conformity is created when the score is 2 , there is partial conformity, and when the score is 3 , overall conformity is created[19].

The assessment standard of the success in the implementation of instruction activity conducted by the teacher, the scoring was based on considering the quality process and result which was classified using Likert 1-5 scale. The scoring provision is when the score was 5, learning instruction component carried out perfectly, the score was 4 when the instruction component conducted was Good, the score was 3 when the instruction component carried out was Quite Good, the score was 2 when the instruction component carried out was Not Good, and the score was 1 when the instruction component did not carry out[27].

The supervisor's final result of supervision activity or academic evaluation is a recommendation based on finding and the fact of the instruction process carried out by the mathematics teacher in the class. Based on the existing score classification, the teachers who get a Very Good (A) and Good (B) ranking will be recommended to attain a reward from the Madrasah principal. Meanwhile, the teachers who get Moderate and Poor ranks will be advised to follow several activities in selfdevelopment programs such as MGMP activity, Education and Training, and IHT related to the instruction of the 2013 curriculum. The progress of teachers' who participate in the self-development program will be monitored once every three months by the Madrasah vice-principal of the curriculum. This monitoring is an attempt to ensure the recommendation provided by the supervisor to the teacher was working and leading to a better direction[28].

Therefore, good supervision typically provides a positive impact on the instruction quality in a Madrasah. When every supervision stage is well managed and has a good relationship among the education provider, the Madrasah will also have good quality. Vice Versa, if the supervision has not yet been understood as the Madrasah quality improvement goal, the school will be hard to enhance its quality. Essentially, the quality of academic supervision is one of the factors which can enhance teachers' professional skills. The academic supervision will be qualified if the implementation was conducted precisely conforming to the teachers' requirements[29].
There is a positive and significant impact between academic supervision by the Madrasah principal on the teachers' teaching performance. It means that if the Madrasah principal's academic supervision is adequate, teachers' performance will be high. The impact of academic supervision on the teachers' professionalism and graduates' quality is that they will know and fix their weaknesses and flaws in learning-teaching activities. Teachers can improve their method of instruction, learning-teaching method, discipline, better teaching quality. The teacher, after being supervised, will be more confident in teaching, student achievement, in terms of academic and non-academic will increase, such as character, ethic, respect each other, enthusiasm in the study, the Madrasah and national subject's grade are good and accepted in State Universities[27].

The implementation of good supervision ideally has a positive influence on the quality of learning in a madrasah. When each stage of the supervision is carried out properly, and there is good cooperation between education providers, the madrasa will have good quality. Therefore, if the supervision process is not understood as a direction for improving the quality of the madrasa, then the madrasah will find it difficult to improve its quality. Because the quality of academic supervision is one of the factors that can improve the professional ability of teachers. Academic supervision will be of high quality if its implementation is carried out appropriately according to the needs of the teacher [23].

The last finding relates to the planning process for the academic supervision of mathematics teachers by the madrasah principals, the plan for a draft schedule for the implementation of academic supervision made by the deputy head of the madrasa in the field of curriculum. From the draft schedule, the implementation of academic supervision of mathematics teachers planned by the madrasah principals is carried out once a school year. The process of organizing academic supervision carried out by the head of the madrasa next is the head of the madrasah holding an official meeting with the supervision team with a meeting agenda, namely discussions related to academic supervision activity plans, division of supervision tasks, and delegation of authority to senior teachers who are appointed as supervisors. In the division of tasks for supervision activities, the supervisor has the task of supervising 3 math teachers [26].

The results of the research findings related to the implementation of classroom learning include the teacher carrying out learning according to the usual teaching schedule; The head/supervisor makes observations or observations of the learning process starting from the opening activities of learning, core learning activities, and closing activities. The supervisor records and provides an assessment of the entire learning process carried out by the teacher [30]. 
The final result of the supervision or evaluation of academic supervision activities that have been carried out by the supervisor is a recommendation based on the findings and facts of the learning process carried out by the mathematics teacher in the classroom. Based on the classification of existing grades, teachers who get very good (A) and good (B) ratings will be recommended to get a reward from the madrasa head while teachers who get sufficient and fewer ratings will get assistance by participating in several teacher self-development activities including teacher's council (Musyawarah Guru Mata Pelajaran) (MGMP) activities, Education and education and training and in-house training related to Curriculum 2013 learning. The development of teachers who carry out self-development programs will be monitored every three months by the deputy head of madrasas in the curriculum field, this is done as an effort to ensure that the recommendations given by supervisors to the teachers concerned are truly continuously and towards a better direction [11].

There is a positive and significant influence between the principal's academic supervision on the teaching performance of teachers. This means that if the principal's academic supervision is effective, the teacher's performance will be high [31]. that the impact of academic supervision on teacher professionalism and the quality of graduates is that teachers know and correct deficiencies and weaknesses in teaching and learning activities; Teachers can improve in terms of learning methods, teaching and learning techniques, class mastery, discipline, better teaching quality; Teachers after being supervised can be more confident in teaching; Student achievement in terms of academic and non-academic increases such as character, ethics, mutual respect, enthusiasm for learning, learning is more fun, communication becomes multi-directional, good school and national exam scores, and is accepted at state universities [32].

Based on the calculation result of the correlation coefficient between academic supervision management by the Madrasah Principals (X) with the quality improvement of mathematic instructions (Y), it can be concluded that there is a positive and significant correlation between academic supervision madrasah by the Madrasah principal (X) with the quality of mathematic instruction (Y) because it was obtained the coefficient correlation score is $\mathrm{r}_{\mathrm{y}}=0.5086$.

The contribution of academic supervision by the Madrasah principal (X) in enlightening teachers' instruction effectiveness (Y) through coefficient determination score ry ${ }^{2}=0.2587(25.87 \%)$ because it was obtained the score of $\mathrm{t}_{\text {count }}=5,336>\mathrm{t}_{\text {table }}=1,66$ in the 0.05 significant level. Thus, it shows that $25.87 \%$ quality improvement of mathematic instruction (Y) can be enlightened by the academic supervision of the Madrasah principal. This research result shows a very significant and positive correlation between academic supervision with the mathematic instruction quality (Y) dan the relation is functional relationship meaning that the increasing role of academic supervision management by the Madrasah principal can enhance mathematic instruction quality (Y). This result is supported, who stated the supervision management could enhance teachers' professionalism[30].

According to the theory on academic supervision of Madrasah principal stressing to the stages of supervision management. Good supervision, ideally, also provides a positive influence on the instruction quality in a Madrasah. When every supervision stage is conducted correctly and good cooperation among all education providers, the Madrasah will also have a good quality[33]. Vice versa, if the educational process has not yet been understood as the direction for the instruction quality improvement, the concerned Madrasah will have difficulty improving its quality. This indication aligns, who argues that the Madrasah principal is an independent academic supervisor required in developing a Madrasah organization[16]. With well-programmed academic supervision management, its implementation conforming to the planning, and upholding the supervision principles and carried out continuously, it will achieve a qualified and classy instruction process services in the Madrasah, and the outcome will increase graduates quality and students' achievement[34]

Thus this study supports previous research with the title " The Relationship between the Transformational Leadership, the Cultural Intelligence of Teachers and the Skills of Principals' Diversity Management" shows that there is a significant positive relationship between the transformational leadership, the cultural intelligence of teachers, and the skills of principals' diversity management, with a correlation coefficient ( $r$ ) of 0.333 at $=0.05$ [6]. It means, the higher the academic supervision of the teacher principal, the higher the effectiveness of teacher learning.

\section{CONCLUSION}

Based on the findings and discussion, it can be concluded that the management of academic supervision by the madrasah principal in improving the quality of mathematics learning and to support school literacy movement in madrasas and has a positive influence, meaning that increasing the role of the madrasah principal's academic supervision management can improve the quality of mathematics learning. Some limitations of this study are as follows: a) the research sample is only limited to madrasah tsanawiyah teachers, and b) mathematics study teachers.

The researcher recommends to other researchers who are acting as the policymaker in education within 
the Madrasah scope of municipality or Regional Offices of Ministry of Religious Affairs that the role of competency enhancement of academic supervision by the Madrasah principal is very strategic in conducting teacher's supervision, coaching, and development and also assuring the learning quality in Madrasah.

\section{AUTHORS' CONTRIBUTIONS}

All authors conceived and designed this study. All authors contributed to the process of revising the manuscript, and in the end, all author have approved the final version of this manuscript.

\section{REFERENCES}

[1] S. C. Kong, Y. Q. Wang, Investigating primary school principals' programming perception and support from the perspective of reasoned action: A mixed-methods approach, Computers \& Education 172, 2021, pp. 104267. DOI: https://doi.org/10.1016/j.compedu.2021.104267

[2] R. L. Bonner, et al., Preparing academics to teach: Example of a structured method of preparing doctoral students in business programs to teach. Journal of Management Education 44(4),2020, pp. 435-463. DOI: https://doi.org/10.1177\%2F1052562920907132

[3] F. Aravena, Á. González, Always ready and always well: Exploring stress on school principals in Chile, International Journal of Educational Development 84, 2021, pp. 102399. DOI: https://doi.org/10.1016/j.ijedudev.2021.102399

[4] Y. S. Sunaryo, Academic Supervision of School Principals and Teacher Performance: A Literature Review, International Journal Pedagogy of Social Studies 5(2), 2020, pp. 17-34. DOI: https://doi.org/10.17509/ijposs.v5i2.29094

[5] C. Glickman, R. W. Burns Supervision and Teacher Wellness: An Essential Component for Improving Classroom Practice, Journal of Educational Supervision 4(1), 2021, pp. 18. DOI: https://doi.org/https://doi.org/10.31045/jes.4.1.3

[6] N. Cobanoglu, The Relationship between the Transformational Leadership, the Cultural Intelligence of Teachers and the Skills of Principals' Diversity Management. European Journal of Educational Management 4(1), 2021, pp. 35-49.

[7] E. Lee, M. Neumann, S. Boese, K. Maaz. Implementation processes of site-based management at schools in challenging circumstances in Germany: Principals' and teachers' perceptions of openness and consensus in target setting processes, Studies in Educational Evaluation 70, 2021, pp. 101003. DOI: https://doi.org/10.1016/j.stueduc.2021.101003

[8] E. P. Gracia, et al, Teachers' professional identity: validation of an assessment instrument for preservice teachers, Heliyon 7(9), 2021, pp. e08049. DOI: https://doi.org/10.1016/j.heliyon.2021.e08049

[9] A. Balyer, H. Karatas, B. Alci, School principals' roles in establishing collaborative professional learning communities at schools, Procedia-Social and Behavioral Sciences 197, 2015, pp. 13401347. DOI: https://doi.org/10.1016/j.sbspro.2015.07.387

[10] N. Shahmohammadi, The relationship between management style with human relations and job satisfaction among guidance schools' Principals in District 3 of Karaj, Procedia-Social and Behavioral Sciences 205,2015, pp. 247-253. DOI: https://doi.org/10.1016/j.sbspro.2015.09.069

[11] E. L. Stosich, Central office leadership for instructional improvement: Developing collaborative leadership among principals and instructional leadership team members, Teachers College Record 122(9),2020, pp. 1-42. DOI: https://doi.org/10.1177\%2F016146812012200908

[12] S. Liu, P. Hallinger, D. Feng, Supporting the professional learning of teachers in China: Does principal leadership make a difference?, Teaching and teacher education 59, 2016, pp. 79-91. DOI: https://doi.org/10.1016/j.tate.2016.05.023

[13] U. Sayee, C. Robert, E. B. Adomako, Supervisory practices and challenges faced by senior high school principals in Greater Monrovia, Liberia: implications for quality education, Heliyon 7(4) ,202, pp. e06895. DOI https://doi.org/10.1016/j.heliyon.2021.e06895

[14] J. Xu, Y. T. Huang, Identity transformation of Chinese secondary school teachers during educational reform, Asian Journal of Social Science, 2021.2 DOI https://doi.org/10.1080/03055698.2021.1886055

[15] S. Saihu, The Urgency Of Total Quality Management In Academic Supervision To Improve The Competency Of Teachers,EdukasiIslami: Jurnal Pendidikan Islam 9(02), 2020, pp. 297-323. 
[16] M. Ozcan, Teachers' Evaluation on School Principals' Supervision, Educational Policy Analysis and Strategic Research 15(2),2020, pp. 303-321.

[17] Kotirde, I. Yuguda, J. B. M. Yunos, The processes of supervisions in secondary schools educational system in Nigeria, Procedia-Social and Behavioral Sciences 204,2015, pp. 259-264. DOI: https://doi.org/10.1016/j.sbspro.2015.08.149

[18] Handayani, Mengoptimalkan Supervisi Akademik Dalam Proses Pembelajaran Di Kelas Upaya Meningkatkan Kompetensi Guru TK PGRI 4 Mataram Semester DuaTahun Pelajaran 2018/2019, JurnalIlmiah Mandala Education 6(1), 2020. DOI: http://dx.doi.org/10.36312/ jime.v6i1.1104

[19] K. Tirri, E. Eisenschmidt, K. P. Valickis, E. Kuusisto, Current Challenges in School Leadership in Estonia and Finland: A MultipleCase Study among Exemplary Principals, Education Research International 2021, 202.DOI: https://doi.org/10.1155/2021/8855927

[20] S. Alispahic, B. Alispahic, A new decade for social changes, Technology and Social Science Journal, 17, pp. 235-243, 2021.

[21] B. Altun, P. Y. Sarkaya, The actors of teacher supervision, Journal of Human Sciences 17(1), 2020, pp. 284-303. DOI: https://doi.org/10.14687/jhs.v17i1.5880

[22] O. J. Ojo, Principals' Management Techniques and Students' Academic Performance in Secondary Schools Ilorin East LGA, Kwara State, Anatolian Journal of Education 3(1), 2018, pp. 21-30.

[23] M. J. Mosoge, S. K. C. Mataboge, Empowerment of the school management team by secondary schools principals in Tshwane West District, South Africa, Educational Research and Reviews 16.4,2021, pp. 93-103.

[24] G. I. Lingam, N. Lingam, S. K. Singh, Instructional leadership practices: Teachers perceptions of a rural school principal in Fiji, Australian Journal of Teacher Education (Online) 46(6), 2021, pp. 20-35. DOI: https://search.informit.org/doi/10.3316/informit.04 5048856938645

[25] M. Ozcan, Teachers' Evaluation on School Principals' Supervision, Educational Policy Analysis and Strategic Research 15(2), 2020, pp. 303-321.
[26] S. A. Tachie, N. C. Mancotywa, Challenges Faced by the Development Support Group in Implementing the Integrated Quality Management System in Circuit 04 Schools in the Mthatha Education District, Education Research International 2021, 2021. DOI: https://doi.org/10.1155/2021/8888539

[27] P. Naidoo, Perceptions of teachers and school management teams of the leadership roles of public school principals, South African Journal of Education 39(2), 2019. DOI: https://doi.org/10.15700/saje.v39n2a1534

[28] K. Webster, P. Litchka, Planning for Effective School Leadership: Teachers' Perceptions of the Leadership Skills and Ethical Behaviors of School Principals, Educational Planning 27(1), 2020, pp. 31-47.

[29] A. M. Alkaabi, S. A. Almaamari, Supervisory Feedback in the Principal Evaluation Process, International Journal of Evaluation and Research in Education 9(3), 2020, pp. 503-509.

[30] U. Deniz, M. A. Erdener, Levels of school administrators exhibiting instructional supervision behaviors: Teachers' perspectives, Research in Educational Administration and Leadership 5(4), 2020, pp. 1038-1081.

[31] G. I. Lingam, N. Lingam, S. K. Singh, Instructional leadership practices: Teachers perceptions of a rural school principal in Fiji, Australian Journal of Teacher Education (Online) 46(6), 2021, pp. 20-35. DOI: https://search.informit.org/doi/10.3316/informit.04 5048856938645

[32] W. Pusporini, C. Triatna, A. Syahid, C.Kustandi, Is the Education Quality in Indonesia Equal? An Analysis on the Findings of Principal Partnerships Program, European Journal of Educational Research 9(3), 2020, pp. 935-942.

[33] U. Bergmark, P. O. Erixon, Professional and academic knowledge in teachers' research: An empowering oscillation, European Educational Research Journal 19(6), 2020, pp. 587-608. DOI: https://doi.org/10.1177\%2F1474904119890158

[34] T. J. Maponya, The Instructional Leadership Role of the School Principal on Learners' Academic Achievement, African Educational Research Journal 8(2), 2020,pp. 183-193. 